\title{
Enquiry Based Approach for Enhanced Learning in DBA Laboratory: A Case Study
}

\author{
Praveen M.Dhulavvagol ${ }^{1}$,Mr. Uday Kulkarni ${ }^{2}$ Dr. Meena S.M. ${ }^{3}$ Mr. Prashant M.N ${ }^{4}$ \\ ${ }^{1,2,3,4}$ Dept of ISE,BVBCET \\ 1 praveen.md@bvb.edu, ${ }^{2}$ uday_kulkarni@bvb.edu, ${ }^{3}$ msm@bvb.edu, ${ }^{4}$ prashant_narayankar@bvb.edu
}

\begin{abstract}
This case study of categorized laboratory is basically to explore the effectiveness of structured enquiry in database application laboratory to encourage inquiry for the undergraduate students of Information Science \& engg department. Enquiry based learning approaches enhance student's learning as compared to the conventional method. In enquiry based approach all the experiments are classified into four categories such as demonstration, exercise, structured enquiry and open ended experiment. During the year 2012-13 and 2013-14 batches, students are compared with respect to their exam score, understanding of concepts, analyzing and implementing the studied concepts, database design and the nature of problem statement given in the laboratory.
\end{abstract}

All the batches are given with different set of unique problem statements to avoid plagiarism and that really encouraged the students to study DBMS subject in depth, and also stimulated them to choose data mining and information retrieval subject, data engineering theme to build the capstone projects in their higher semesters.

Praveen M.Dhulavvagol

Dept of ISE,BVBCET

praveen.md@bvb.edu
This enquiry-based laboratory conduction has enhanced the students learning skills, stimulated to acquire content knowledge, problem solving skills, asking questions, and coming up with alternate design approaches for given problem. The results of this two years study give us a clear differentiation that inquiry based approach is better for students to acquire in depth knowledge and problem solving skills as compared to traditional approach where there was no categorization of lab experiments.

Keywords-Program outcomes, program educational objectives, structured enquiry, open ended experiments.

\section{Introduction}

Outcomes-based education has become a major focus in teaching and learning process. Over the past few years we at BVB College of Engineering and Technology has stressed the importance of outcomebased education in design of curriculums and teaching pedagogy. Outcome-based education seems to be a new concept adopted in teaching database application lab.

In conventional method of teaching were there was no categorization of experiments. Students used to solve the given task with the same approach i.e. the method was

Fixed, they lack in realizing the need of doing that experiment what is the learning objective and 
outcome [7]. Is rarely to have a correlation-ship with students to know What is expected knowledge to be achieved at the end of the course. Student will be unable to correlate the concepts to build an application and not able to figure out where to apply these concepts how to formulate and design the appropriate solution for a given problem.

So unless and until the course outcome is presented clearly and precisely the students will not get to know the need and usage of that course.

PEO of Information Science \& Engg Department, BVBCET

1. Apply the knowledge of mathematics, computer science and engineering to successfully develop computer based systems and processes dynamically to meet customer business objectives.

2. Acquire communication and interpersonal skills to function effectively, both individually and within a team in their professional careers.

3. Recognize legal, ethical and professional responsibilities and contribute positively to the society.

4. Engage in lifelong learning to remain current in their profession, pursue higher studies and be leaders in the technological society.

\section{Literature Survey}

Inquiry-based learning is a process where students are involved in learning, formulate questions, investigate widely and then build new understandings, meanings and knowledge. This knowledge is new to the students and may be used to answer a question, to develop a solution or to support a position or point of view. The knowledge is usually presented to others and will result in some sort of action [1]. The practical challenges of designing laboratory learning with in modern engineering curriculum have many challenges the primary focus is to enhance the student learning [2]. A student centred learning approach is one where the student is actively involved in the learning process. Enquiry based learning is a particular type of student centred approach which encourages students to seek out information and through discussion to develop a better understanding of the subject of study[4]. Lifelong learning is the ongoing, voluntary, and self- motivated pursuit of knowledge for either personal or professional reasons. Therefore, it not only enhances social inclusion, active citizenship, and personal development, but also self-sustainability, rather than competitiveness and employability [5].

OBE is a method of curriculum design and teaching that focuses on what students will achieve after studying a particular course [6]. In outcome based learning, learning outcomes (knowledge, skills and competences) to be achieved by learners are in the focal point of the learning process. All educational activities and resources need to be related to the intended learning outcomes of a learning module or course, in order to assist the learners in successfully achieving the intended learning outcomes at the end of the learning experience. Outcome based assessment means that the assessment process must be aligned with the learning outcomes. This means that it should support the learners in their progress (formative assessment) and validate the achievement of the intended learning outcomes at the end of the process (summative assessment) [7]

\section{Key Paradigm Shift}

Students become less prone to ask questions as they move through the grade levels. First of all we need to make changes in our curriculum to adopt OBE [6]. Basically OBE is student centered learning that focus on measuring students' performance.

The different challenges faced in designing new curriculum to map OBE are as listed:

To provide students with the knowledge and techniques to effectively design and manage database application Projects and to develop a career in a related industry.

To analyze and apply the concepts to develop the project.

To develop soft skills (communication and presentation).

Design of the program outcomes and performance indicator and CLO's.

Mapping the program outcome to Program Educational

Outcomes (PEO).

The laboratory and project work is a major contribute towards achieving Abet a-k criteria the table 1 illustrate the abet $a-k$ criteria [3]. 
Table 1: List of Programme Outcomes

\begin{tabular}{|c|c|}
\hline $\begin{array}{l}\text { Programme } \\
\text { Outcomes }\end{array}$ & Descriptions \\
\hline $\mathrm{PO}(\mathrm{a})$ & $\begin{array}{l}\text { An ability to apply knowledge of mathematics, } \\
\text { computer science and engineering }\end{array}$ \\
\hline $\mathrm{PO}(\mathrm{b})$ & $\begin{array}{l}\text { An ability to analyze a problem, identify and } \\
\text { formulate the computing requirements } \\
\text { appropriate to its solution. }\end{array}$ \\
\hline $\mathrm{PO}(\mathrm{c})$ & $\begin{array}{l}\text { An ability to design a computer based system, } \\
\text { component or process to meet the desired needs } \\
\text { within realistic constraints. }\end{array}$ \\
\hline $\mathrm{PO}(\mathrm{d})$ & $\begin{array}{l}\text { An ability to apply knowledge of engineering and } \\
\text { project management to function individually as } \\
\text { well as a team member in various roles of a } \\
\text { multidisciplinary team. }\end{array}$ \\
\hline $\mathrm{PO}(\mathrm{e})$ & $\begin{array}{l}\text { An ability to identify, formulate and solve } \\
\text { complex engineering problems which uses } \\
\text { computer based systems. }\end{array}$ \\
\hline $\mathrm{PO}(\mathrm{f})$ & $\begin{array}{l}\text { An understanding of professional and ethical } \\
\text { responsibilities relevant to computer engineering }\end{array}$ \\
\hline $\mathrm{PO}(\mathrm{g})$ & $\begin{array}{l}\text { An ability to communicate and present } \\
\text { effectively in oral and written form. }\end{array}$ \\
\hline $\mathrm{PO}(\mathrm{h})$ & $\begin{array}{l}\text { Students will have the broad education necessary } \\
\text { to understand the impact of computer } \\
\text { engineering solutions in a global/societal context. }\end{array}$ \\
\hline PO (i) & $\begin{array}{l}\text { A Recognition of the need for and an ability to } \\
\text { engage in lifelong learning }\end{array}$ \\
\hline $\mathrm{PO}(\mathrm{j})$ & Knowledge of contemporary issues. \\
\hline $\mathrm{PO}(\mathrm{k})$ & $\begin{array}{l}\text { An ability to use the techniques, skills, and tools } \\
\text { necessary for computer engineering practice. }\end{array}$ \\
\hline
\end{tabular}

Table 2: List of selected programme and course outcomes for ISL302 [DBA Lab]

\begin{tabular}{|c|l|l|l|}
\hline $\begin{array}{c}\text { Programme } \\
\text { Outcomes }\end{array}$ & $\begin{array}{l}\text { Outcome } \\
\text { Element: }\end{array}$ & $\begin{array}{l}\text { Performance } \\
\text { Indicator }\end{array}$ & $\begin{array}{l}\text { Course } \\
\text { Learning } \\
\text { Outcomes }\end{array}$ \\
\hline PO (a) & $\begin{array}{l}\text { OE(a)-1 } \\
\text { applity to } \\
\text { knowledg } \\
\text { of Mathe } \\
\text { matics }\end{array}$ & $\begin{array}{l}\text { Ability to apply } \\
\text { knowledge } \\
\text { of }\end{array}$ & $\begin{array}{l}\text { Numerical } \\
\text { methods, } \\
\text { settheory } \\
\text { Populate } \\
\text { and query a } \\
\text { database using } \\
\text { SQLDML/ } \\
\text { DDLcommands. }\end{array}$ \\
\hline PO (b) & $\begin{array}{l}\text { OE (b) -2 } \\
\text { Ability to } \\
\text { identify } \\
\text { and } \\
\text { formulate } \\
\text { problem }\end{array}$ & $\begin{array}{l}\text { Define data } \\
\text { types and data } \\
\text { structures } \\
\text { needed for a } \\
\text { given } \\
\text { computing } \\
\text { Problem }\end{array}$ & $\begin{array}{l}\text { CLO1:Analyze } \\
\text { given data and } \\
\text { design an ER } \\
\text { model for a } \\
\text { database } \\
\text { system }\end{array}$ \\
\hline
\end{tabular}

\begin{tabular}{|c|c|c|c|}
\hline \multirow[t]{2}{*}{$\mathrm{PO}(\mathrm{c})$} & $\begin{array}{l}\text { OE }(\mathrm{c})-2 \\
\text { Ability to } \\
\text { design a } \\
\text { system/pr } \\
\text { ocess with } \\
\text { due } \\
\text { considerat } \\
\text { ion to } \\
\text { societal } \\
\text { impact. } \\
\text { OE (c) -3 } \\
\text { An Ability } \\
\text { to design } \\
\text { a computer }\end{array}$ & $\begin{array}{l}\text {-Ability to } \\
\text { explore } \\
\text { designal } \\
\text { ternatives } \\
\text {-Ability to } \\
\text { evaluate } \\
\text { feasibility of } \\
\text { alternatives } \\
\text { and propose } \\
\text { appropriate } \\
\text { solution by } \\
\text { considering } \\
\text { the realistic } \\
\text { constraints. }\end{array}$ & $\begin{array}{l}\text { CLO1:Analyze } \\
\text { given data and } \\
\text { design an ER } \\
\text { model for a } \\
\text { database } \\
\text { system } \\
\text { CLO3:Underst } \\
\text { and how } \\
\text { to design datab } \\
\text { ases according } \\
\text { to normalization } \\
\text { standards } \\
\text { CLO4: Design } \\
\text { and implement }\end{array}$ \\
\hline & $\begin{array}{l}\text { based } \\
\text { system, } \\
\text { componento } \\
\text { process to } \\
\text { meet } \\
\text { desired } \\
\text { needs }\end{array}$ & & $\begin{array}{l}\text { a real-world } \\
\text { data base } \\
\text { application }\end{array}$ \\
\hline PO (g) & $\begin{array}{l}\text { OE(g)-1An } \\
\text { Ability to } \\
\text { document } \\
\text { and } \\
\text { communic } \\
\text { ate } \\
\text { effectively } \\
\text { OE (g) -2 } \\
\text { An Ability } \\
\text { to present } \\
\text { effectively }\end{array}$ & $\begin{array}{l}\text {-Ability to } \\
\text { write } \\
\text { laboratory } \\
\text { reports, } \\
\text { including } \\
\text { figures, tables } \\
\text { and graphs. } \\
\text {-Ability to } \\
\text { present the } \\
\text { result sand } \\
\text { conclusions. }\end{array}$ & $\begin{array}{l}\text { CLO4: Design } \\
\text { and implement } \\
\text { a real-world } \\
\text { data base } \\
\text { application. }\end{array}$ \\
\hline
\end{tabular}

Table 3: Mapping of PEO to PO

\begin{tabular}{|l|l|l|l|l|}
\hline PO & PEO1 & PEO2 & PEO3 & PEO4 \\
\hline Criteria "a" & & & & \\
\hline Criteria "b" & & & & \\
\hline Criteria "c" & & & & \\
\hline Criteria "g" & & & & \\
\hline
\end{tabular}

Table 4: Lab Categorization

\begin{tabular}{|l|l|c|c|c|}
\hline \multirow{2}{*}{ Categorization } & \multicolumn{4}{|c|}{ Parameters } \\
\cline { 2 - 5 } & Aim & Material & M ethod & Solution \\
\hline Demonstration & Specified & Specified & Given & Given \\
\hline Exercise & Specified & Specified & Given & open \\
\hline Structured Enquiry & Specified & Specified & open & open \\
\hline $\begin{array}{l}\text { Open Ended } \\
\text { Enquiry }\end{array}$ & Specified & open & open & open \\
\hline
\end{tabular}




\section{Structured Enquiry Approach}

In structured enquiry approach the aim of an experiment is given along with the required material here the students need to choose appropriate met hod to solve the given problem. The solutions are not fixed it depends on how each and every student analyze the given problem statement based on his analysis he is going to design the solution applying the appropriate method to get the required output.

Here in enquiry based approach input and out put are not fixed it varies with respect to each of the students

based on the method what they have applied to solve the problem.

Inquiry implies involvement that leads to understanding. Furthermore, involvement in learning implies possessing skills and attitudes that permit you to seek resolutions to questions an d issues while you construct

new knowledge [6].

This structuredenquiry base $\mathrm{d}$ approachis drivenby students wherethe faculty incharge justacts likean initiator.

The main advantages of enquiry based approach:

Students thinking ability is enhanced

Analyzing and design skills are developed Plagiarism is avoided

In-depth understanding of the subject

Stimulate the students to study the subject beyond The course content

Understand various technologies

Life long learning 9 projects and research work Usage of tools

Enquiry based approach is a student centric approach were he/she can showcase the innovativeness and creativity in solving the given problem which will basically enhance their learning skills and problem solving abilities with different approaches.

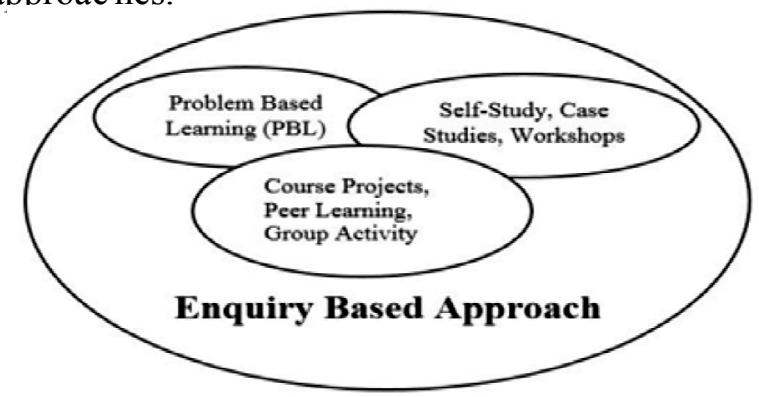

Figur e 1: EBA
In conventional method practice students used to carry out PBL, self-study and course projects separately. From the above Figure. 1we can depict that enquiry based approach provides the collaborative platform of all the above phases.

Table 5: Collaborative Approach

\begin{tabular}{|l|c|c|c|}
\hline \multicolumn{1}{|c|}{$\begin{array}{c}\text { Enquiry Based } \\
\text { Learning Features }\end{array}$} & PBL & $\begin{array}{c}\text { Self Study, } \\
\text { Case } \\
\text { Studies, } \\
\text { Workshops }\end{array}$ & $\begin{array}{c}\text { Course } \\
\text { project, } \\
\text { Group } \\
\text { Activity }\end{array}$ \\
\hline $\begin{array}{l}\text { Context based } \\
\text { learning on application } \\
\text { domains. }\end{array}$ & $\sqrt{ }$ & $\sqrt{ }$ & $\sqrt{ }$ \\
\hline $\begin{array}{l}\text { Open end and course } \\
\text { project. }\end{array}$ & $\sqrt{ }$ & $\sqrt{ }$ & $\sqrt{ }$ \\
\hline Self-directed learning & $\sqrt{ }$ & $\sqrt{ }$ & $\sqrt{ }$ \\
\hline $\begin{array}{l}\text { Peer learning } \\
\text { (teamwork) }\end{array}$ & $\sqrt{ }$ & $\sqrt{ }$ & $\sqrt{ }$ \\
\hline
\end{tabular}

The above table 5 provides the features of enquiry based learning which resulted into following outcomes.

Provides a relevant and cumulative framework for effective learning.

Questioning and searching for answers will lead into conceptual context for learning.

Understand, correlate and apply the concepts to solve problems.

Thinking, creativity and problem sol ving skills are enhanced.

\section{Case Study}

Dababase Application lab workflow:

The below figure 2 gives the DBA lab process flow

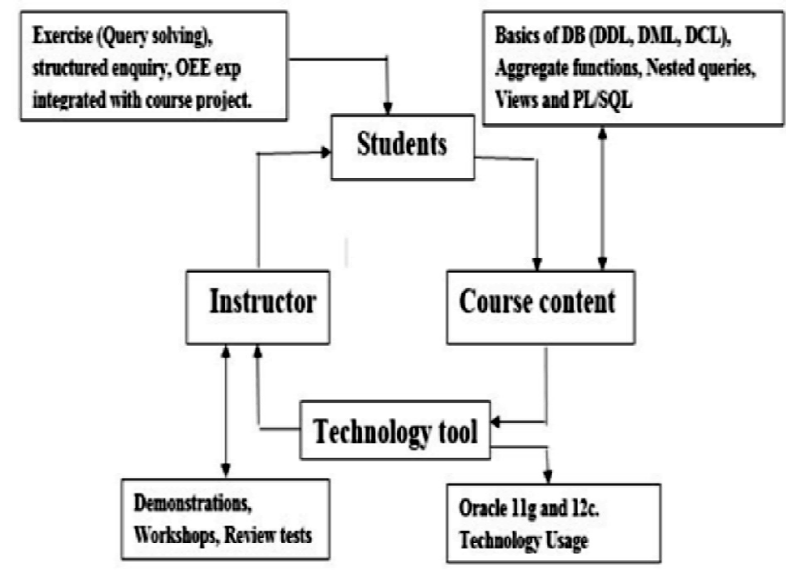

Figure 2: Lab Process 
DBA laboratory basically involves study ing of RDBMS concepts and realization of the PL/SQ L statements. Students are able to understand and implement solution for real time miniworld/scenarios and implem ent the same. Students are able to identify the possible optimized query in terms of memory utilization and performa nce. Content of DBA lab is basically focused on implementation and hands on experience with integrated projects. Each batch will have different set of mini world/problem de scription so that plagiarism should be avoided.

This approach enables the students to understand and use the tools to implement the ORACLE concepts. OEE integrated with course projects helps the stu dents to acquire communication and interpersonal skills, team work and lifelong learning.

Lab Conduction Process:

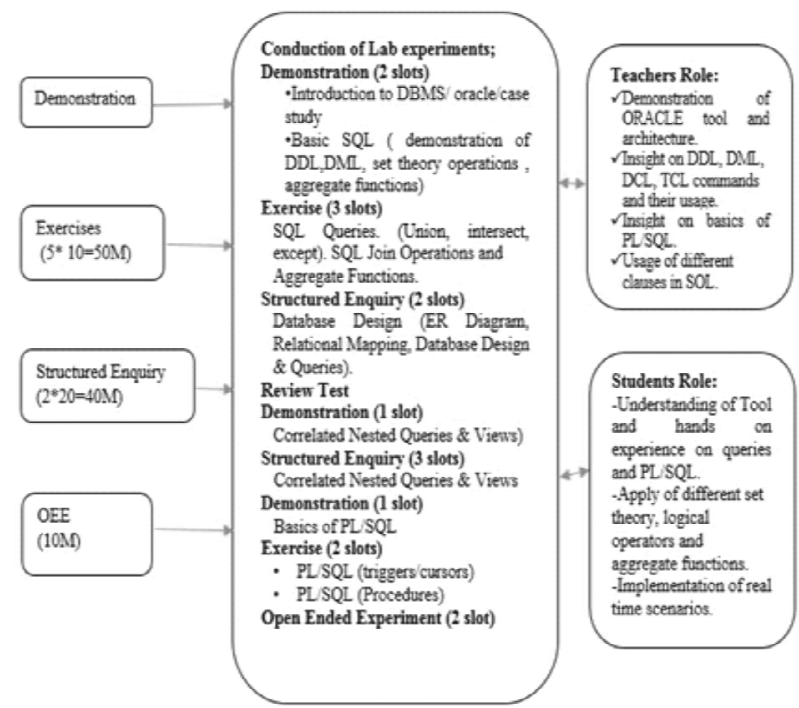

Figure 3: Lab Conduction Framework

\section{Student Learning Framework}

The Framework for St udent Learning outlines the relationships among placemen $t$, capstone projects, RUE projects, technology learning like big-data (Hadoop) and understanding the concepts involved in subjects like data mining, Information Retrieval.

Student explorative learning [4] of database concepts like Indexes, Trigge rs, Views and basics of $\mathrm{PL} / \mathrm{SQL}$ will help them to get recruited in product/service based companies. DBA labs sti mulate students to carry out Capstone projects and RUE projects and engage them in lifelong learning.

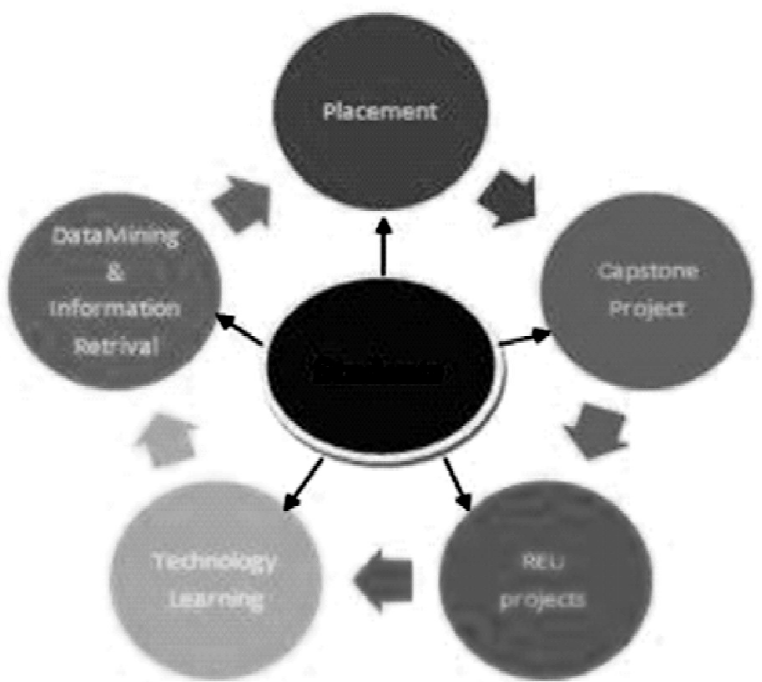

Figure 4: Student Learning Framework

\section{Achivements And Analysis}

By categorizing the lab experiments, attainment of PEO, PO's mapping to the Abet criteria a, b, c, g are as shown in the above table $2 \& 3$. Analysis of last three academic years is as shown in the below figure 4 . The results confirmed that the student's engagement in understanding and applying the concepts helped to meet out the learning outcomes.

Result analysis of past few years interprets that there was improvement in student performance from grade $\mathrm{C}$ to $\mathrm{B} 17.1 \%$ and $\mathrm{B}$ to $\mathrm{A} 20.9 \%$. This performance has encouraged students to carry out capstone and REU projects in data engineering theme, Big Data and Hadoop technology.

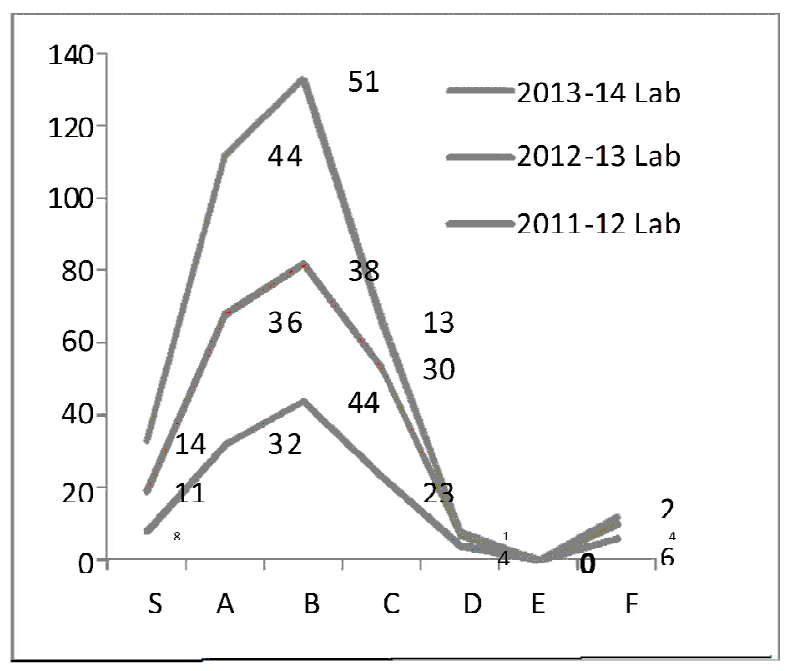

Figure 5: Result Analysis 
Online Feedback Survey

Questionnaires:

1. Design of the experiments helped in understanding RDBMS concepts?

2. OEE and structured enquiry has enhanced self learning and creative thinking.

3. Categorization of lab experiments enhanced your problem solving abilities.

4. The lab experiments helped in realization of concepts to achieve the objectives and outcome of the course.

5. DBA lab has stimulated to engage in lifelong learning.

The below figure 6 diplicts the students feedback on the above mentioned questionnaries

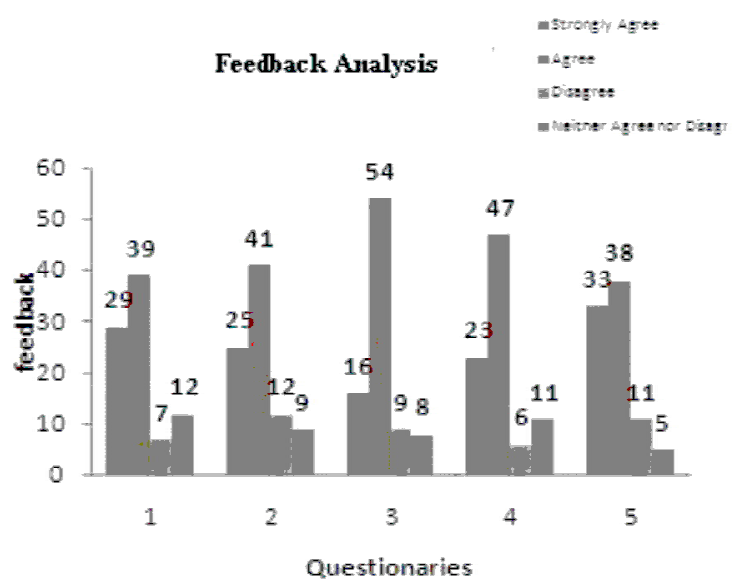

Figure 6: Feedback Analysis

The feedback analysis clearly shows $76-80 \%$ of students agreed that enquiry based learning approach has enhanced their learning and problem solving skills.

\section{Conclusion}

Enquiry Based Learning resulted in better performance as it was taken up and carried out by students through which they exposed the ability of self learning and to carry out industry projects and REU. Even we observed the fact that they performed very well in SEE of lab and theory subjects. Enquiry based approach has enhanced student learning and problem solving skills. Feedback given by the company and passed out students helped us in forming the structured plan for DBA lab. In future we aim to improve the laboratory categorization effectively to enhance the student learning and guide them for better placement and carrier.

\section{References}

[1] "Focus on Inquiry", Alberta Learning, Alberta, Canada, 2004

[2] "Learning and Teaching in Laboratories" an Engineering Subject Center guide by Clara Davies, 2008

[3] Accreditation Board of Engineering and Technology, "Criteria forAccreditingEngineering Programs:Effective for Evaluations duringt $\mathrm{h} \quad \mathrm{e}$ 2000-2001 Accreditation Cycle," 2000

[4]"The Impact of Student Centered Learning: An Evaluation of Tutor and Student Experiences "Helen Crabtree, 2006

[5] Evers, T., J. Rush, and I. Berdrow. 1998. The Bases of Competence: Skills for Lifelong Learning and Employability. San Francisco: Jossey-Bass.

[6]Acharya, C. Outcome-based education (OBE): A new Paradigm for learning. Centre for Development of Teaching and Learning (Singapore), 7(3). 2003

[7] Crespo, R. M., Najjar, J., Derntl, M., Leony, D., Neumann, S., Oberhuemer, P\& Kloos, C. D. Aligning assessment with learning outcomes in outcome-based education. In Education Engineering (EDUCON), 2010 IEEE (pp. 12391246). IEEE. 2010, April. 